\title{
Understanding Femi Osofisan's Once upon Four Robbers and Aringindin and the Nightwatchmen: A Critical Perspective
}

\author{
C. O. Ajidahun ${ }^{1}$ \\ ${ }^{1}$ P. M. B. 001, Adekunle Ajasin University, Ondo State, Nigeria \\ Correspondence: C. O. Ajidahun, P. M. B. 001, Adekunle Ajasin University, Akungba-Akoko, Ondo State, \\ Nigeria. Tel: 234-803-392-7663 \& 234-805-801-7164. E-mail: jideajidahun@yahoo.co.uk
}

Received: May 3, 2012

Accepted: June 7, $2012 \quad$ Online Published: August 21, 2012

doi:10.5539/ells.v2n3p115

URL: http://dx.doi.org/10.5539/ells.v2n3p115

\begin{abstract}
The paper is a critical discourse on Femi Osofisan's Once upon Four Robbers and Aringindin and the Nightwatchmen. The paper discusses the playwright's view on the inefficacy of death penalty as a measure to curb the intractable menace of armed robbery in Nigeria. It also addresses the underlying stifling economic factors responsible for the prevalence of armed robbery in the society. Such factors include unemployment, hunger, poverty, inflation, greed, hoarding, graft, corruption, deprivation, injustice, and ridiculous salary structure. The paper notes the playwright's delineation of the State as a terrorist, which lacks the moral capability to eradicate armed robbery through death penalty without first providing its citizens with the basic infrastructure. Finally, the article observes that Femi Osofisan deliberately uses the platform of drama to ridicule at the powerlessness of the death penalty decree, which will never be able to curb the pervasiveness of armed robbery in the society until the fundamental factors are addressed.
\end{abstract}

Keywords: Osofisan, Once upon Four Robbers, Aringindin and the Nightwatchmen, armed robbery, death penalty, society

\section{Introduction}

Once upon Four Robbers is a reaction to the decree promulgated by General Gowon's administration that made armed robbery punishable by public execution. The play, which is set in a market place, is structured into a Prologue, Parts One to Three, an Interlude and an Epilogue, with an opening glee that is similar to the classical theatrical prologue in which an entrance song or chant often precedes the play.

The story teller presents the play in the traditional African folktale style of performance in which the story teller begins with "Alo...o!" and everybody replies "A...lo!" He repeats this and gets the same response. He then begins to play his musical instruments and starts singing and the audience picks the refrain-ALUGBINRIN GBINRIN! As the song gathers momentum, the musician, the actors within the audience begin to assemble on the stage (1).

The adoption of such indigenous mode and aesthetics, according to Ukala (1996, p.285):

will make the play authentic at home... and ... may also be a means of communication between characters, often replacing dialogue or function as a soliloquy, intimating to the audience the singer's hidden thoughts and traits. They may bolster up a character to confront a dreadful obstacle, create a spell, or induce a trance.

Osofisan, in the Programme Notes to the text, states unequivocally his vision in the play:

The phenomenon of armed robbery seems to me an apt metaphor for our age. But its reality outside the stage is of course far more brutal, devoid of any romanticism. With all our decrees and edicts, we have no succeeded in taming this singular aspect of the violence of the age. And the problem has grown intractable, worsening with each passing day. The legalized slaughtering of the erring members of our society for whatsoever offence will certainly not bring the restoration of our society to its primordial sanity. For armed robberies, on the scale we are witnessing, are the product of our unjust society. I hope it (the play) helps to change our attitude from passive acceptance or sterile indignation into a more dynamic, more enraged determination to confront ourselves and our lives. Else the four robbers will continue to rule our streets. (viii) 
Osofisan is displeased with the wanton murder of armed robbers but wants us to have a rethink about the whole issue, or else, robbers and violence will continue to reign in the society.

The play, which centers on four whose names are: Angola, Major, Hasan and Alhaja, begins on a mournful note with Alhaja sobbing over the killing of her husband, Alani, the leader of the robbers who is convicted for armed robbery and executed. Alhaja sings a slow dirge for her late husband as the robbers vow to revenge. Hence, the robbers do not only boast of their previous successful raids at UAC, Mapo, and Customs and so on, they continue to become a nuisance to the society and a thorn in the flesh of the state. The State Security apparatus is incapable of putting them under control, while the death penalty decree only worsens the situation.

Alani, their leader, has been executed, yet the robbers vow to revenge. One then wonders about the essence of the death penalty decree. It therefore means that there are many sides to the issue of armed robbery. That is what Oluode (p.16) in Aringindin and the Nightwatchmen means when he says:

What the Alagba means

Kansilor, is that people

like you see only

the menace of robbers

whereas our problem

has much deeper roots...

What Oluode is saying in essence is that armed robbery is not the real problem in the society. What then is the real problem?

The answer to this question is the essence of the play. Osofisan, in this text, indicts the State and the society for the menace of armed robbery. Osofisan believes that man is not naturally depraved but that man is a victim of the stringent socio-economic policies made by government. Such draconian policies make it difficult for man to realize himself as an upright and responsible being. Survival therefore becomes a game of the fittest and only the bravest can survive it like Kunle in Birthdays Are not for Dying who believes that the world is full of cannibals and only the toughest survive it. Claudius in The Oriki of a Grasshopper also says that man is born into a world of cats where only the fiercest survive. For man to survive therefore, he needs to feed on the others.

Osofisan believes that these four robbers are the products of an unjust society where the wealth of the land is unevenly distributed. The oppressors keep getting richer and richer and the oppressed keep getting poorer and poorer. The poor are human beings too. They have needs like the rich. Should they remain silent in the face of this injustice and resign to fate? Akinrinade (1985, p.41) seems to have an answer. He says:

This is the lot and orientation of all members of the society since there is uneven distribution of wealth: the few who are rich flaunt their wealth in the face of the many poor ones. The rich did not make their money through honest means. Therefore, the poor who do not have anywhere to turn to also want money in order to flaunt it in the face of other citizens. Hence, crime is the logical avenue.

In this play, Osofisan is more concerned about the causes of armed robbery rather than its consequences on the society. It is the society that encourages issues of unemployment, hunger, hoarding, inflation, embezzlement of public funds and ostentations. The playwright wants us to take a look at: "the ridiculous salary structures, minimum wage, the squalid spending habits of our egregious "contractors" land speculators, middle men of all sorts, importers, exporters etc, slums and ghettoes, congested hospitals, crowded schools, impossible markets, proliferation of motor cars, insurance agencies, supermarkets, chemist shops, boutiques, discotheques etc" (viii). Osofisan is convinced that unless government takes a look at all these, the problem of armed robbery will continue unabated in the society.

The robbers in the play even identify the reasons why they rob innocent citizens. Major, one of the robbers, says "Forgive us. It is hunger that drives us." (p.14) Hasan on the other hand says:

We're doomed, my brother; and only our solidarity saves us. From the cutting of the cord, earth to earth. You know the myths! What else do they recount but the unending tales of the powerless against the strong? And it's a history of repeated defeat, oppression, of nothing changing... (p.60)

In their search for a way out of the stifling economic difficulties in which they have been trapped, Aafaa gives them a magic chant that is capable of making them rob successfully without violence. In the face of unemployment, hunger and deprivation while the rich openly display their wealth, resort to armed robbery may therefore be inevitable. 
Osofisan snarls at the State and ridicules the powerlessness and inefficacy of its resort to public execution as a way of eradicating the malaise. That is why Fatoba (1996, p.81) calls the State a terrorist:

The position of the State in this circumstance is to fight terror with terror. The Yoruba refer to this as cursing a curse (malady) with another curse (malady); (K'a f'epe w'epe); that is setting two negative forces against each other like the proverbial two wrongs which do not make a right.

Osofisan in one of his articles entitled: "The Elephants Are Dying," published in the Sunday Times of August 27, 1989 , laments the sordid state of the oppressed in the society. He says that is why there is an increase in the crime rate in the nation:

Violence dodges our every step: the commonest metaphor of our streets nowadays is that of the gun, carried by the robber, or the soldier, or the black robed sergeant at the police "Chop-point". Markets go on rowdy by the sides of abandoned corpses; suspects are picked off the streets for "wandering" and then forgotten to rot in prison cells; school children hardly out of diapers routinely assault their teachers with astonishing ruthlessness, smash their school rooms and laboratories, or go gleefully rampaging on the streets... The vast majority of the children, however, would be offspring of struggling families. The parents would be either wretched farmers, road hawkers or petty traders whose total yearly income could never pay the school fees or buy books and uniforms... Men and women in their prime lose their sense of dignity, and their sanity, after weeks of walking the streets without employment, and take to foraging like dogs in city dustbins... Where is the room in all this misery, to think of animals, or of trees? In Nigeria, the elephants that are dying are human beings. (p.5)

Osofisan sounds convinced that the death penalty as a means of wiping out armed robbery is an exercise in futility. Writing on the inefficacy of death penalty for eradicating armed robbers and drug barons, Osofisan in an article entitled "Not a Gift for Christmas" published in the Sunday Times of December 3, 1989 opines that

There is sufficient evidence, as things now stand, that if we approve the death penalty once again, we will kill all the couriers unfortunate enough to be caught, but we will not, however, halt the crime of drug trafficking itself For some time, perhaps the traffic will slow down, but it will resume again over the corpses of the slain. Like our unending battle with armed robbers, where there are no victors and no losers, the battle against the drug carriers will continue to gobble defaulters, but they will be rapidly replaced by new candidates. In the end, what will be dying at the executioner's stake may well be our collective sensibility as human beings, and our always fragile capacity for feeling, and for compassion (p.5).

Osofisan tries to show in Once upon Four Robbers that every member of the society is guilty of crime or the other. He wonders how some members of the society can pass a death sentence on a criminal when they themselves cannot be exonerated from criminal activities. For instance, Major, one of the robbers in the text outsmarts and betrays the other robbers by stealing away all the money jointly stolen. Major, after the incident, tells his accomplices his aspirations in life:

This is money! Money! A new life. No more scurrying in the smell of back streets. A house the size of a palace! The law, tamed with my bank account! And children! Listen, I am going to be a daddy! I'II own the main streets, six, no...ten Mercedes, the neon lights, the supermarkets... (p.39)

Major, like the greedy and selfish rich people in the society, is not interested in settling down for a decent job or in investing whatever money he has into an honest business, rather, he is interested in ostentatious and extravagant spending. Eventually, he is shot by the soldiers. That represents one very important aspect of the society.

The playwright gives a true picture of this situation in one of his newspaper publications entitled "My Gratitude to FIFA" published in the Sunday Times December 17, 1989. He observes regrettably:

For our nation is a nation of mindless ostentation. We are committed, both the rich and the poor, to the worship of surface glitter. As I go round the streets nowadays, I am struck by this display, all around, of wastefulness amidst the most dreadful squalor. I go from the bus-stops with their pathetic riotous scenes, and the armies of ever-increasing beggars at road junctions, to a street which has been closed off at both ends, and decorated with canopies. Here, I find myself suddenly in a different world and the men and women seem like characters in a grandiloquent fairy tale. They are lavishly dressed and gorgeously turned out. They are lavishly dressed and gorgeously turned out. They have abundant laughter and glittering gold teeth. Jewels surround their neck, and fill their hair. The band in attendance begins a tune and calls out a name, and these colorful fairies troop out, and begins to shower their hero with currency notes. The first to stop is the one who retreats in disgrace... Urchins and offspring of the wretched in the neighborhood have come scrounging for food, fight for left-overs, 
empty half-eaten plates into plastic bags, scoop up the rice fallen to the floor... Nobody questions why some should have so much to "spray" while others pick their food at their feet. (p.5)

It is ridiculous to see a great number of the people in the society wallowing in poverty while the rich people are openly and arrogantly displaying their wealth without having the slightest compassion for the poor. This situation breeds crimes. It is absurd for such people who bulldoze themselves to the leadership positions in the society to pass a death sentence on the poor robbers who resort to armed robbery as a protest against the injustice and other socio-economic forces in the society.

Osofisan in Esu and the Vagabond Minstrels addresses these socio-economic forces like the issues of unemployment and poverty as contemporary experiences in Nigeria. In the play, the five vagabonds are driven to the crossroad as a result of lack of employment. This is because government has proscribed the profession of the musicians. It is dehumanizing for a man to be driven to the crossroads in search of food brought there as a sacrifice for Esu. To worsen their condition, their search is in vain as the whole place as described by Epo Oyinbo is "a barren as a graveyard" (p.5).

The playwright seems to be saying that, the era of wasting food on a useless and meaningless sacrifice is over. Yet, the vagabonds are hungry. They are thus described as "living corpses and their stomach a furnace in rioting embers" (p.6). Jigi cries out and says "Hunger makes a life meaningless" (p.6). Osofisan laments the state of the oppressed and the poor in one of his articles entitled "Like a Fire in a Freezing Night" published in the Sunday Times of June 25, 1989. According to him:

Poverty is in the household, oppression in the air we breathe... If a free society cannot save the many who are poor, it cannot saved the few who are rich... a society cannot save the many who are poor, it cannot itself be a free society... Poverty degrades the people; it decays governments. (p.5)

Osofisan is so much concerned about the condition of the poor that he berates the National Assembly for making things difficult for the former President Olusegun Obasanjo and for its contemplation on his impeachment over what the legislators call a breach of protocol. Osofisan considers the President's bill, which has to do with how to fight poverty and unemployment more important than issues of protocol and furniture allowance. Osofisan, in his article entitled "When Will the Rain Get to Abuja?" published in The Comet of Sunday January, 20, 2000 is of the view that

What one expects is that the legislators will concern themselves first and foremost with the problems of rampant hunger and unemployment, with the crisis in the educational and industrial sectors, the discredited police and such things. Instead of "Stop Obasanjo" the cry we want most to hear is "Stop Poverty! Arrest Decadence! End Desolation! Wipe Away Hunger and Squalor!"” (p.10)

Apart from Major in Once upon Four Robbers who contributes to the sufferings and oppression of the poor, the market women to like Mama Alice Mama Toun, Mama Uyi, Bintu like the shop owners in Aringindin and the Nightwatchmen. This they do through hoarding of goods and thereby creating artificial scarcity of goods which eventually will lead to inflation. Invariably when there is inflation, only the rich will be able to afford to buy goods irrespective of their prices, while the poor continue to forage for food at odd and shameful places.

Osofisan reveals this aspect of the attitude of the market women through the "Song of the Market":

The work of profit

brought us to this world...

The lure of profit

has conquered our souls

and changed us into cannibals...

We make inflation

and hoard away

as much as we may relish

essential commodities

like sugar and salt

like milk and oil

so we can leave the market 
each day a-rolling in wealth!

The lust of profit

keeps us in this world

this life that is a market,

refuse to join and perish

rebel and quench

For those who spit at gold,

\section{Otosi asinniwaye!}

The song is an indictment on the greedy business men and women in the society who use their ventures to exploit and oppress the masses through hoarding and creation of arbitrary and unjustifiable increase in prices of goods and services. Whenever these people are attacked by armed robbers, they will put the blame on the robbers and on the inability of the police to curb armed robbery in the country whereas they too are robbers and economic saboteurs. The poor die gradually in their hands as a result of their lust for profit and craze for wealth.

Osofisan supports this in his article entitled: "Because of Rice: published in The Guardian of Sunday, October 6, 1958. He observed that

The real enemy is the trader in our midst, the one who, to survive, must perennially create artificial shortages... There must be very few families in the land where there is nobody earning his or her living by commerce. Thus, even as we protest against the practice of hiking prices for selfish greed, we all practice it, or eat from those who do so. How do we then stop ourselves from continuously harming ourselves? ... Or is there a way of altering the cruel ways of our traders', our collective propensity for profiteering? (p.9)

Besides, even the contractor who is supposed to build the execution platform for the armed robbers refuses to complete this job. Instead, he goes ahead to buy a flashy Mercedes Benz car. In addition, he takes new wife, using government money while the poor continue to languish in poverty. This contractor is not different from armed robbers. Somebody who dies from the bullets of armed robbers may not feel the pangs of death as much as the poor man who dies as a result of hunger. The contractor, Major and their likes are more criminal than the notorious armed robbers in the society.

In addition, the Sergeant provides false information on his tax form in order to get a rebate. Even Soldier 1 tells us about his vision for the country when he becomes a commissioned officer in the army. Instead of bringing justice to the people and alleviating the suffering of the poor through equitable distribution of the nation's resources, the soldier wants to declare "all the fine palaces on Victoria Island and Ikoyi, all the better lands at Ibadan, Kaduna, Pitakwa" for himself under the guise of declaring them for government. And if the owners of the lands should protest, he will detain them (p.46). This is a dignified way of robbery.

Even Aafaa, a religious leader like Baba Soye in Farewell to a Cannibal Rage, Baba Fawomi of Who's Afraid of Solarin? and Pastor Suuru in Midnight Hotel because of the lure of money, abuses his office by collaborating with the robbers. He gives them some spiritual charms that will make them succeed in their robbery operations. Virtually all the characters in the play use different methods to rob the people.

One can therefore understand the position of Osofisan as highlighted in his article entitled. "Not a Gift for Christmas" published in the Sunday Times of December 3, 1989 when he asserts:

My belief is that a society which drives its citizens to such acts of desperation has no moral right to take their lives for such actions. Murder, even when officially sanctioned, is still not a proof of higher morality (p.5).

The playwright is very hopeful that the death penalty decree will be abrogated in the future through a revolution that will sweep away all the socio-economic forces confronting the society. Major, at the firing block captures this when he tells the Sergeant:

Serg, today that law is on the side of those who have, and in abundance, who are fed, bulging, who can afford several concubines? But tomorrow, that law will change. The poor will seize it and twist its neck. The starving will smash the gates of the supermarkets; the homeless will no longer yield in fear to your bulldozers. And your children, yes, your dainty, little children will be here, where I stand now, on the firing block (p.63).

The play ends on a debate and stalemate as the other robbers led by Angola and with the use of incantations clash with the soldiers at the execution ground as "the stage vibrates with the clashing orders of soldiers and robbers. In that confusion, everything suddenly comes to a freeze". (p.71) 
The question, therefore, is whether armed robbers should be shot or not? But the position of Osofisan is very clear; death penalty is not the solution to the menace of armed robbery in the society. Osofisan is provoking the audience to have a deep and enraged thought about it all. He wants government to address the basic needs of the poor in the society and see to the equitable distribution of the nation's resources. The playwright, in a tone of anger and hopelessness foresees no end to the menace of armed robbery until the stifling socio-economic forces in the society have been tackled.

\section{References}

-----. (1985). Because of Rice. The Guardian, 9. 6 Oct.

-----. (1989). Like a Fire in a Freezing Night. Sunday Times, 5. 25 June.

-----. (1989). My Gratitude to FIFA. Sunday Times, 5. 17 Dec.

-----. (1989). Not A Gift For Christmas. Sunday Time, 5. 3 Dec.

-----. (1989). The Elephants Are Dying. Sunday Times, 5. 27 Aug.

-----. (2000). When Will the Rain Get To Abuja. The Comet, 10. 30 Jan.

Akinrinade, N. A. (1985). Social Responsibility of the Artist: The Plays of Femi Osofisan, (An Unpublished M. A. Thesis). Department of English, University of Ibadan.

Fatoba, F. (1996). The State as Terrorist: Once Upon Four Robbers. In Muyiwa Awodiya (Ed.), Femi Osofisan: Interpretive Essays I (pp. 81-87). Lagos: Centre for Black and African Arts and Civilization.

Osofisan, Femi. (1978). Who's Afraid of Solarin? Calabar: Scholars' Press.

Osofisan, Femi. (1980). Once upon Four Robbers. Ibadan; Heinemann.

Osofisan, Femi. (1986a). Farewell to a Cannibal Rage. Ibadan: Evans Publishers.

Osofisan, Femi. (1986b). Midnight Hotel. Ibadan: Evans Publishers.

Osofisan, Femi. (1986c). Two One-Act Plays: The Oriki of a Grasshopper and Altine's Wrath. Ibadan; New Horn Press.

Osofisan, Femi. (1990a). Birthdays Are Not For Dying and Other Plays. Lagos: Malthouse Press.

Osofisan, Femi. (1990b). The Inspector and the Hero. Lagos: Malthouse Press.

Osofisan, Femi. (1991). Esu and the Vagabond Minstrels. Ibadan: New Horn Press.

Osofisan, Femi. (1992). Aringindin and the Nightwatchmen. Ibadan: Heinemann.

Ukala, Sam. (1996). 'Folkism': Towards a National Aesthetic Principle for Nigerian Dramaturgy. New Theatre Quarterly, 12(47), 279-287. http://dx.doi.org/10.1017/S0266464X00010277 